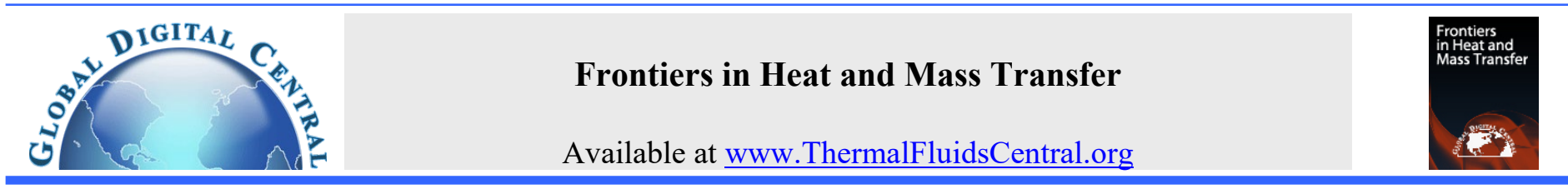

\title{
TEMPERATURES DEPENDENT DRYING KINETICS OF COCOA BEANS VARIETIES IN AIR-VENTILATED OVEN
}

\author{
M.A. Waheed ${ }^{\mathrm{a}}$ and C.A. Komolafe ${ }^{\mathrm{b}, *}$ \\ ${ }^{a}$ Department of Mechanical Engineering, College of Engineering \\ Federal University of Agriculture, P.M..B. 2240, Abeokuta, Nigeria \\ ${ }^{b}$ Department of Mechanical Engineering, College of Engineering \\ Landmark University, P.M.B. 1001, Omu Aran, Nigeria
}

\begin{abstract}
The drying kinetics of three varieties of cocoa beans (N38, F and WA) at 40, 50 and 60 degree centigrade was investigated experimentally. The three different varieties were dried using laboratory air oven UF Memmert and the moisture content determined according to AOAC standards. The results show that drying processes occur mainly in the range of the falling-rate period and the drying rates were observed to be faster at higher drying temperature. The effective diffusivities of the three cocoa beans varieties determined at 40,50 and 60 degree centigrade ranged between $9.9269 \times 10^{-}$ ${ }^{11}$ and $4.4671 \times 10^{-10}$ metre square per second. The predicted Arrhenius constant and activation energy were $2.47 \times 10^{-10}$ metre square per second and 23.61 kilojoule per mole.

Keywords: Drying kinetics, drying rate, cocoa beans, drying temperature, moisture content, cocoa varieties
\end{abstract}

\section{INTRODUCTION}

Cocoa beans are seeds of Theobroma cacao L., which is one of the most important cash crop trees in many tropical countries including Nigeria, Cote D'voire, Ghana, Indonesia, Cameroun, Brazil, Ecuador, Malaysia, Sierra-Leone and Republic of Benin. The return of civilian administration in Nigeria in 1999 ushered in a good fortune for cocoa industry with the establishment of the National Cocoa Development Committee (NCDC) in 2000 which is domiciled in the Federal Ministry of Agriculture and Rural Development (FMA\&RD) (Alamu, 2013).

In order to promote the production of cocoa to meet the needs of expanding industrial sector and export market, a special programme tagged cocoa re-birth was launched in 2005 . The policy thrust of the programme was to promote the production of cocoa to meet the needs of an expanding industrial sector and export market (Alamu, 2013). The programme also aimed at creating jobs and wealth to enhance farmers' income and reduce poverty in the country (FGN, 2006). The end products of cocoa beans especially chocolate and beverages are considered among the basic food in many countries of the world and the quality of these end products is a function of how they are processed. The processes to condition cocoa beans for industrial use include a series of steps to develop sensorial properties. The steps include an adequate pod maturity, pod cracking and seed extraction, fermentation, drying, selection and storage (Schwan et al., 1995).

Among these postharvest processing steps, fermentation and drying are the major steps that must be carried out.

Drying, being the most important among other postharvest steps, is a complex thermal process in which unsteady heat and moisture transfer occur simultaneously. This complex process depends on different parameters such as air temperature, relative humidity, air velocity, physical properties and initial moisture content of the product (Akpinar et al., 2003). The main purpose of drying process is to reduce water activity of the material so as to prevent the growth of microorganisms and to lower the activity of enzyme, thereby prolonging the shelf life at room temperature (Hamrouni-Sellami et al., 2013). In drying process, heat is supplied for vaporization of water with unheated and heated forced air. This process through which vaporization of water occur as a result of heat supply to the product is known as simultaneous heat and mass transfer (Hall, 1980). The challenge of cocoa drying has been one of using available sources of energy efficiently to reduce moisture to safe storage levels, while producing beans of acceptable quality (Bonaparte, 1998). In many processes, improper drying may lead to irreversible damage to product quality and hence a non-sellable product (Fagunwa et al., 2009). These are likely consequences of under-drying or over-drying of the product when suitable drying conditions such as drying air temperature are not applied.

Several research works have been reported on the drying kinetics of cocoa beans under different conditions (Chineye et al., 2010; Hii et al., 2009; Fagunwa et al. 2009; Hii et al. 2012; Hii et al., 2010; Hii et al., 2013; Dina et al., 2015; Komolafe et al.,2014) and other agricultural products such as fish (Komolafe et al., 2013; Komolafe et al., 2011), pepper (Darvish et al., 2013), beetroot (Kaur and Singh, 2014), banana (Adewale et al., 2015), persimmon fruits (Sampauo et al., 2016), carrot slices (Doymaz, 2016), green soybean seeds (Zhao, 2017), grain sorghum (Sadaka and Atungulu, 2018), asparagus root (Kohli et al., 2018), banana peels (Lin and Cze, 2018) and sage leaves (Doymaz and Karasu, 2018). A search through the literature shows that work has not been reported on the drying kinetics of these three varieties of cocoa beans (N38, F3 and WA) under oven-drying conditions. This paper presents the drying kinetics of three varieties of cocoa beans under air- 
ventilated oven drying condition at different temperature. The general objective was to determine the best drying condition for each variety using air-ventilated oven.

\section{MATERIALS AND METHODS}

\subsection{Sample preparation}

Firm, ripe, mature, undamaged, cocoa pods, free from infection (visually detected) were collected from Cocoa Research Institute of Nigeria (CRIN), the beans were removed and fermented for six days inside perforated wooden boxes. At every 48 hours, the beans in the boxes were mixed for better fermentation (Hii and Tukimon, 2002; Hii et al. 2010). The three varieties of cocoa beans were fermented separately for 6 days. After the fermentation process, the beans were cleaned of the pulp by soaking in running water (Abdullah, 2003).

\subsection{Drying procedure}

The initial and final moisture content of the three different varieties of cocoa beans (Amelonado, N38; F3 Amazon, F and WACRI Series, WA) were determined by drying samples with laboratory air-ventilated oven (UF. 75 Memmert, Schwabach, Germany, Number: F.-0109.0088) at temperature 40,50 and $60{ }^{\circ} \mathrm{C}$ and air velocity $2.7 \mathrm{~m} / \mathrm{s}$. The experimental set up is as shown in Fig. 1. The setting temperature of the universal oven ranged between 20 and $300{ }^{\circ} \mathrm{C}$. Prior to placing the samples in drying chamber after fermentation, the oven pre-set at $40{ }^{\circ} \mathrm{C}$ was allowed to run for at least 30 minutes to obtain steady condition. Thereafter, $0.5 \mathrm{~kg}$ each of cocoa beans from the three varieties already spread on clean aluminum tray was placed on the shelves inside the oven. The reduction in weight was taken at 30 minutes interval using an electronic scale DT-1000 with a precision of $0.01 \mathrm{~g}$ until no further changes in mass were observed. Losses in samples weight were recorded for moisture content determination. The same procedure was repeated for the varieties at 50 and $60{ }^{\circ} \mathrm{C}$ drying temperatures. To measure the mass of sample at any time during experimentation, sample inside the aluminum tray was taken out of the drying chamber and weighted on the digital/electronics scale (DT-1000) with accuracy of $0.1 \mathrm{~g}$ positioned very close to the oven and then placed back into the drying chamber. The procedure was repeated until a constant weight was obtained.

\subsection{Drying kinetics}

The moisture content on wet basis was calculated according to AOAC (2000) as:

$$
\mathrm{M}_{\mathrm{t}}=\frac{W_{i-} W_{b d}}{W_{i}}
$$

where $M_{\mathrm{t}}$ is the moisture content (\% w.b.); $W_{\mathrm{i}}$ the initial weight of the sample (g) and $W_{\text {bd }}$ the bone dried weight of sample $(\mathrm{g})$.

The dimensionless moisture ratio (MR) of cocoa beans was calculated according to Dinani et al. (2014) using:

$$
M R=\frac{M_{t}-M_{e}}{M_{o}-M_{e}}
$$

where $M_{\mathrm{i}}, M_{\mathrm{e}}$, and $M_{\mathrm{t}}$ are the initial moisture content, equilibrium moisture content and the moisture content measured at time $\mathrm{t}$, respectively. The value of $\mathrm{M}_{\mathrm{e}}$ is very small compared to $\mathrm{M}_{t}$ or $\mathrm{M}_{\mathrm{i}}$ for long drying time. Thus Eqn. (2) can be written in a more simplified form according to El-Sebaii and Shalaby [33] as:

$$
M R=\frac{M_{t}}{M_{o}}
$$

The drying rate (DR) of cocoa beans was calculated using eqn. (4) (Doymaz, 2009; Fernando and Amarasinghe, 2016):

$$
D R=\frac{M_{t}-M_{t+d t}}{d t}
$$

where $M_{t+d t}$ is moisture content ( $\mathrm{g}$ water/g wet solid) at $\mathrm{t}+d t$, $\mathrm{t}$ is the time (hr) and $d t$ is time difference (hr).

The drying rate is defined as diffusion of moisture from the inner to the surface layer. This can be explained by Fick's second law of diffusion for unsteady state diffusion.

\subsection{Moisture diffusivity}

The experimental data were fitted to determine the moisture diffusivity by using the Fick's second law of diffusion:

$$
\frac{\partial M}{\partial t}=D_{e f f} \nabla^{2}
$$

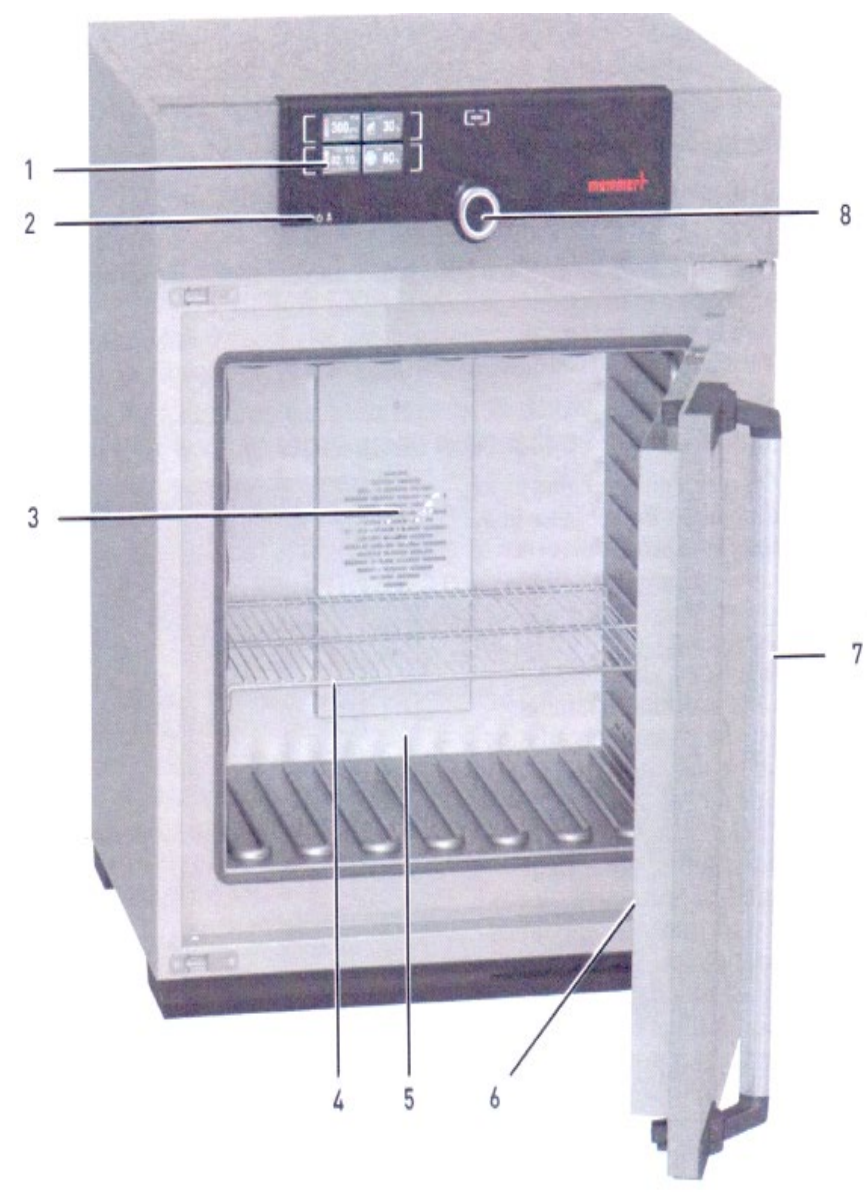

Fig. 1: Features of Memmert oven (1. Control Cockpit with capacitive function key; 2. On/Off switch; 3. Working chamber fan; 4. Steel grid; 5. Working chamber; 6 . Nameplate; 7. Door handle; 8 . Turn control with confirmation key)

Source: (Memmert Expert in Thermostatics , 2013) 
The analytical solution of Eqn. (5) was given by Crank (1975) for slab geometry with uniform initial moisture distribution, negligible external resistance, constant diffusivity and negligible shrinkage as:

$$
M R=\frac{8}{\pi^{2}} \sum_{n=1}^{\infty} \frac{1}{2 n-1} \exp \left(\frac{(2 n-1)^{2} \pi^{2} D_{e f f} t}{4 L^{2}}\right)
$$

where $L$ is half-thickness of the samples (m), $\mathrm{t}$ is the time (s), $\mathrm{n}$ is a positive integer and $D_{\text {eff }}$ is effective diffusivity.

Linearizing Eqn. (6) (Clement et al. 2009; Doymaz, 2005) yields:

$$
\ln (M R)=\ln \left(\frac{8}{\pi^{2}}\right)-\left(\frac{\pi^{2} t D_{e f f}}{4 L^{2}}\right)
$$

The slope of the curve from the plot of $\ln (\mathrm{MR})$ versus drying time was used to determine the effective diffusivity as follows:

$$
D_{\text {eff }}=\text { slope } \times \frac{4 L^{2}}{\pi^{2}}
$$

The activation energy (E) for diffusion was determined using the Arrhenius equation:

$$
D e_{f f}=D \exp \left(-\frac{E}{R T}\right)
$$

where $\mathrm{D}$ is the pre-exponential factor of the Arrhenius equation $\left(\mathrm{m}^{2} / \mathrm{s}\right)$, $\mathrm{E}$ is activation energy $(\mathrm{J} / \mathrm{mol}), \mathrm{R}$ is universal gas constant $(8.314$ $\mathrm{J} / \mathrm{mol} / \mathrm{K})$, $\mathrm{T}$ is absolute temperature $(\mathrm{K})$.

The Microsoft Excel SOLVER tool was used for the prediction of the Arrhenius constant and activation energy.

\section{RESULTS AND DISCUSSION}

Figures 2-4 depict the variation of moisture contents (w.b.) with the drying time during air-oven drying process of three varieties of cocoa beans at 40,50 and $60{ }^{\circ} \mathrm{C}$ drying air temperature. In all cases it can be seen that the moisture contents decrease exponentially with time as reported for most agricultural products by Toujani et al. (2013). The continuous decrease in the moisture content with drying time and increase in temperature resulted in the reduced drying time. At $40{ }^{\circ} \mathrm{C}$, it took 25 hours to reduce the moisture content of N38, F3 and WA from the initial values of $53.8,52.4$ and $50.5 \%$ w.b. to $7.5,4.1$ and $6.4 \%$ w.b., respectively. Similarly, at $50{ }^{\circ} \mathrm{C}$, the reduction of initial moisture content from $53.7,53.6$ and $53 \%$ w.b. to $2.7,2$ and $3.1 \%$, respectively took 20 hours, while at $60{ }^{\circ} \mathrm{C}$, it took 12 hours to reduce the initial moisture content of the cocoa beans from $52.6,51.8$ and $49.6 \%$ to 2.6 , 2.8 and 5.0, respectively. The drying processes at 40,50 and $60^{\circ} \mathrm{C}$ occur mainly in the range of the falling-rate period. This shows that diffusion is the dominant physical mechanism governing moisture movement in the drying samples. The curves show that the increase in drying temperature resulted in the decrease in the drying time since both the thermal gradient inside the object and the evaporation rate in the product increased. The drying time at $50^{\circ} \mathrm{C}$ is more than one and half times that at $60^{\circ} \mathrm{C}$ and double at $40{ }^{\circ} \mathrm{C}$. However, McDonald et al. (1981) stated that drying within a very short time is not recommended and it should be avoided because adequate time is required for oxidation process to occur within the beans in order to ensure full brown of the interior.

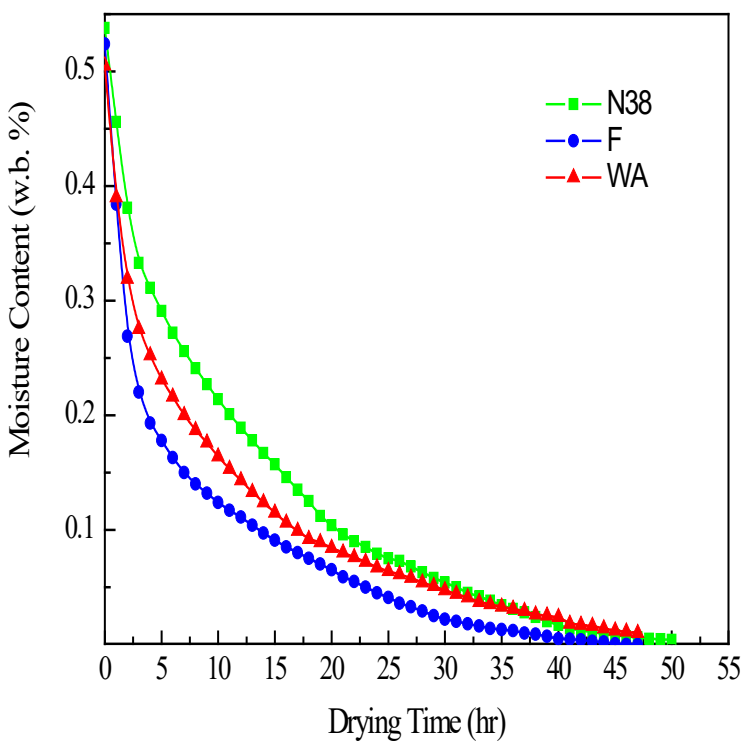

Fig. 2: Variation of moisture content with drying time at $40{ }^{\circ} \mathrm{C}$ drying temperature

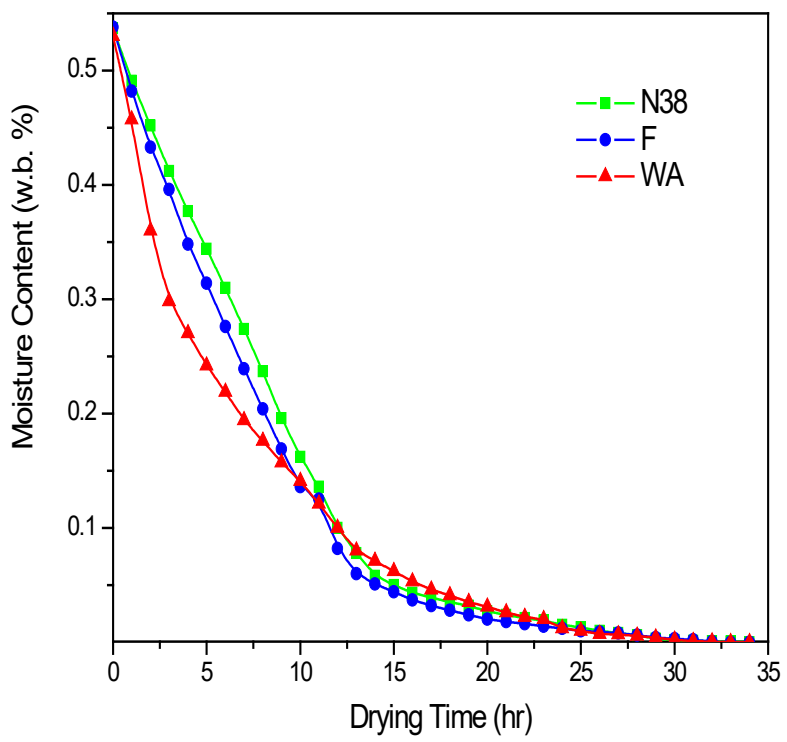

Fig. 3: Variation of moisture content with drying time at $50{ }^{\circ} \mathrm{C}$ drying temperature 


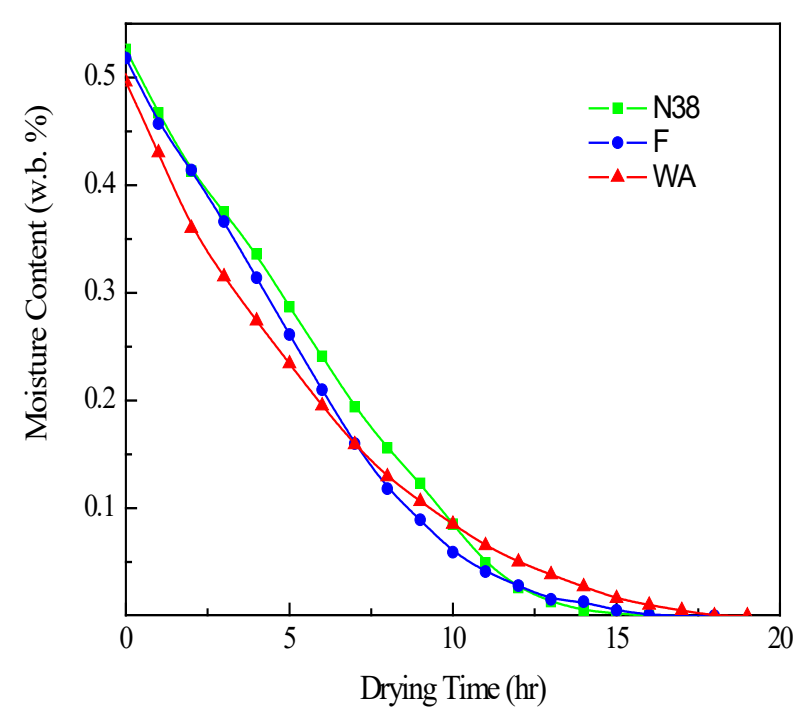

Fig. 4: Variation of moisture content with drying time at $60{ }^{\circ} \mathrm{C}$ drying temperature

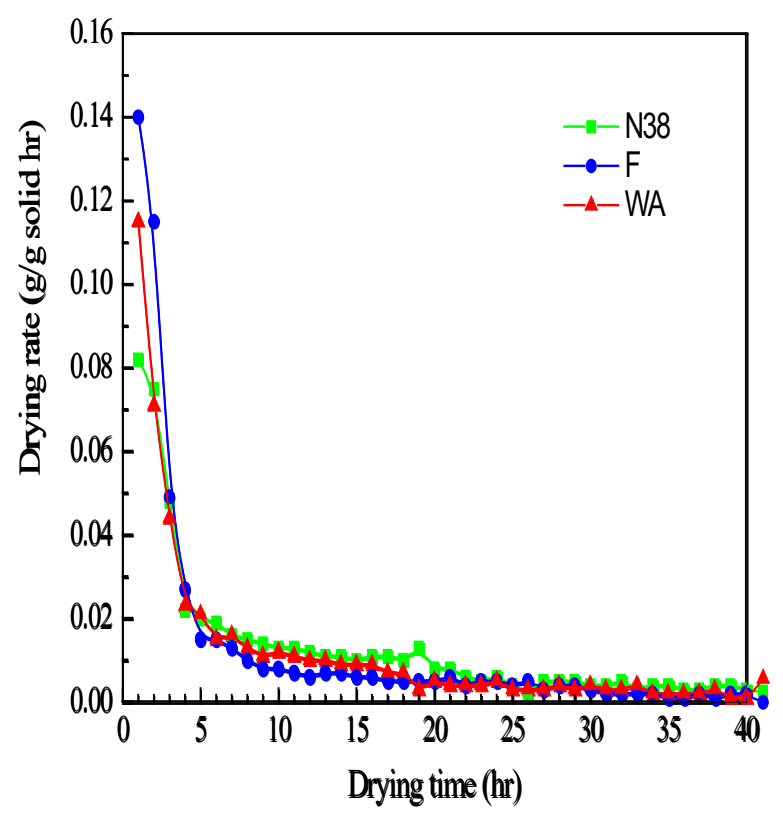

Fig.5: Drying rate as a function of time at $40{ }^{\circ} \mathrm{C}$ drying temperature

Figures 5-7 are plots of the drying rate against the drying time. As expected, the drying temperature has significant effects on the drying kinetics of the varieties. As expected, the highest drying rates occurred during the early hours of the drying processes at 40,50 and $60{ }^{\circ} \mathrm{C}$ for the three varieties (N38, F3 and WA) as presented in Table 1. It was observed that among the three tested varieties, the WA has the highest drying rates at 50 and $60{ }^{\circ} \mathrm{C}$ during the early hour of the drying process.

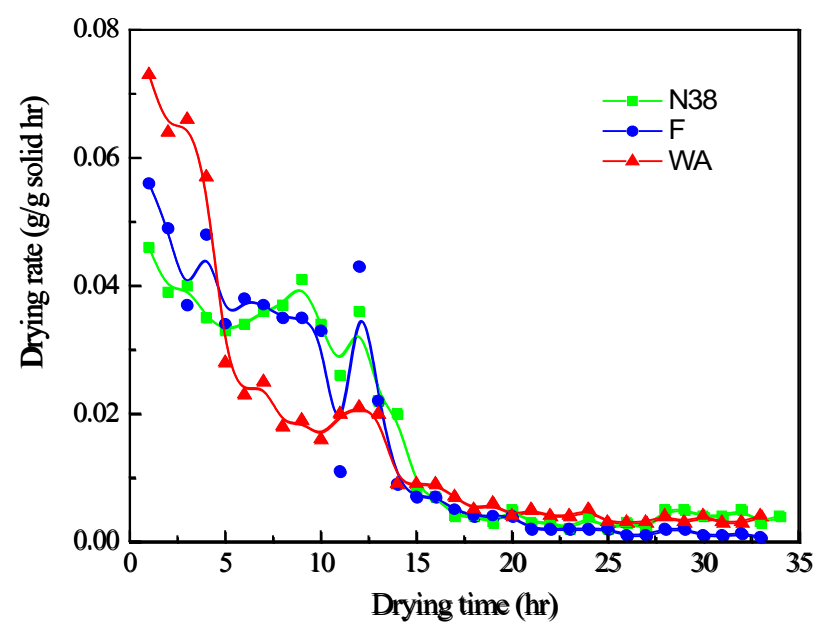

Fig.6: Drying rate as a function of time at $50{ }^{\circ} \mathrm{C}$ drying temperature

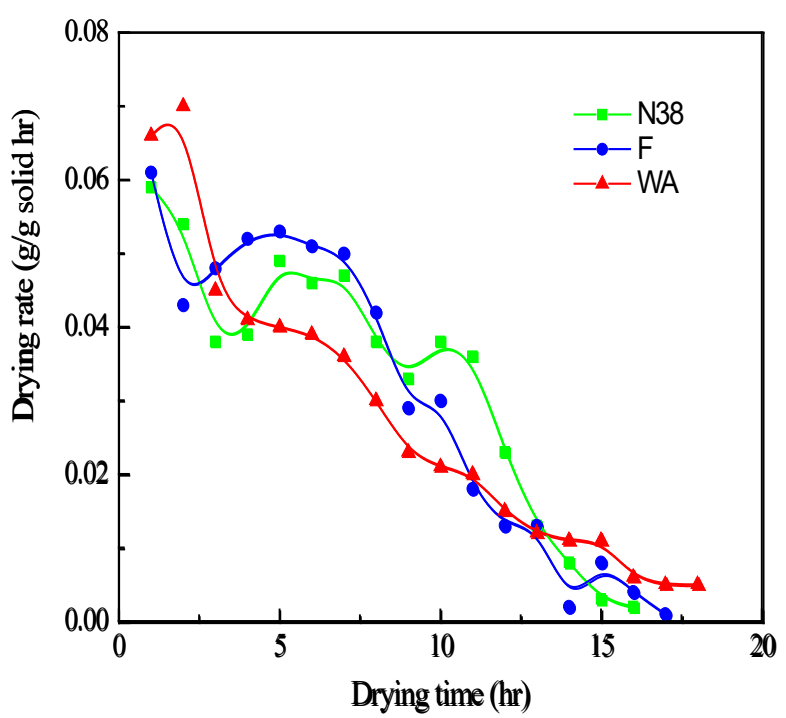

Fig.7: Drying rate as a function of time at $60{ }^{\circ} \mathrm{C}$ drying temperature

Table 1: Calculated drying rate ( $\mathrm{g}$ water $/ \mathrm{g}$ wet solid $\mathrm{hr}$ ) for the different varieties of cocoa beans

Drying rate (g water/g wet solid hr)

Temp.

$\left({ }^{\circ} \mathrm{C}\right)$

\begin{tabular}{cccc} 
& $\mathrm{N} 38$ & $\mathrm{~F} 3$ & $\mathrm{WA}$ \\
\hline & 0.082 & 0.115 & 0.115 \\
40 & & & \\
50 & 0.046 & 0.056 & 0.073 \\
60 & 0.059 & 0.043 & 0.070 \\
\hline
\end{tabular}




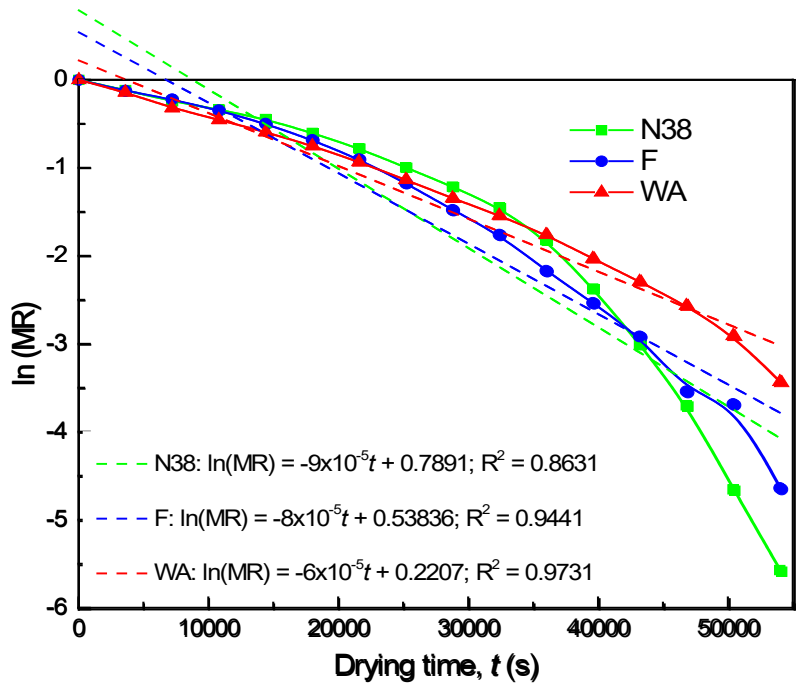

Fig. 8: Variation of logarithm of moisture ratio with drying time at $40{ }^{\circ} \mathrm{C}$ drying temperature

Figures 8-10 present the variation of logarithm of moisture ratio with drying time at 40,50 and $60{ }^{\circ} \mathrm{C}$ drying air temperature. It is clearly evident from the figures that the logarithm of moisture ratio decreased with increase in drying time. The calculated effective diffusivities for cocoa beans at 40,50 and $60^{\circ} \mathrm{C}$ are shown in Table 2 . The values of $D_{\text {eff }}$ obtained from this study lie within the general range $10^{-12}$ to $10^{-8}$ for drying of garlic slices and food materials as presented by Madamba $e t$ al. (1996) and Zogzas et al. (1996). Also, the values lie within the effective diffusivity range $7.46 \times 10^{-11}$ to $1.87 \times 10^{-10} ; 8.94 \times 10^{-11}$ to $9.63 \times 10^{-11} ; 3.70 \times 10^{-11}$ to $5.80 \times 10^{-11}$ and $6.137 \times 10^{-10}$ to $2.1855 \times$ $10^{-9} \mathrm{~m}^{2} / \mathrm{s}$ reported by Hii et al. (2013); Dina et al. (2015); Clement et al. (2009) and Chinenye et al. (2010) during oven-drying at 60, 70 and $80{ }^{\circ} \mathrm{C}$; solar drying integrated with absorbent and adsorbent; sun drying; and heated batch drying of cocoa beans, respectively.

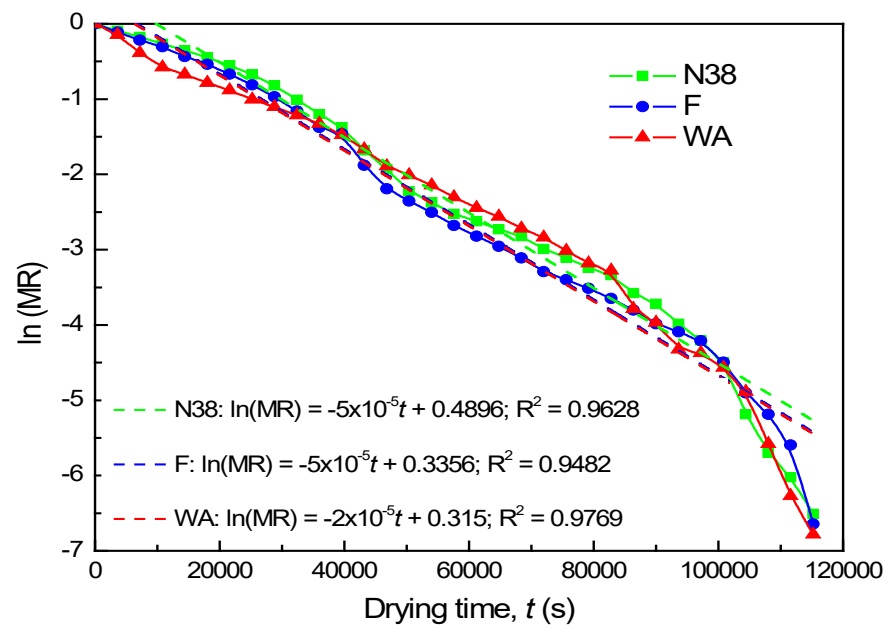

Fig.9: Variation of logarithm of Moisture ratio with drying time at 50 ${ }^{\circ} \mathrm{C}$ drying temperature

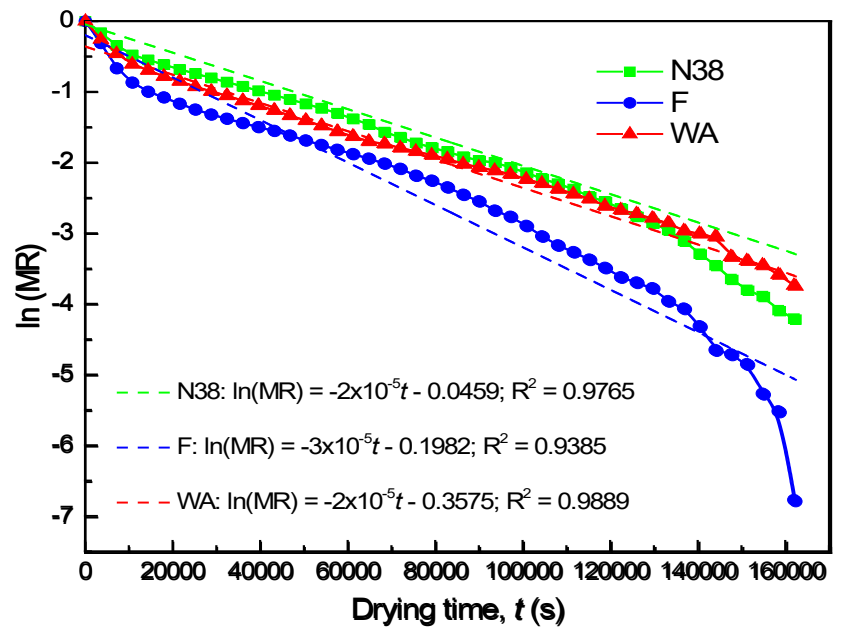

Fig.10: Variation of logarithm of moisture ratio with drying time at $60{ }^{\circ} \mathrm{C}$ drying temperature

Table 2: Calculated moisture diffusivity, $\mathrm{D}_{\text {eff }}\left(\mathrm{m}^{2} / \mathrm{s}\right)$ for the different varieties of cocoa beans

\begin{tabular}{|c|c|c|c|}
\hline \multirow{2}{*}{ Variety } & \multicolumn{3}{|c|}{ Diffusivity $\left(D_{\text {eff }}\right)\left(\mathrm{m}^{2} / \mathrm{s}\right)$} \\
\hline & $40^{\circ} \mathrm{C}$ & $50{ }^{\circ} \mathrm{C}$ & $60^{\circ} \mathrm{C}$ \\
\hline N38 & $9.9269 \times 10^{-11}$ & $2.4817 \times 10^{-10}$ & $4.4671 \times 10^{-10}$ \\
\hline F3 & $1.1681 \times 10^{-10}$ & $1.9469 \times 10^{-10}$ & $3.1150 \times 10^{-10}$ \\
\hline WA & $8.0408 \times 10^{-11}$ & $2.0102 \times 10^{-10}$ & $2.4122 \times 10^{-10}$ \\
\hline
\end{tabular}

\section{CONCLUSION}

Drying kinetics of cocoa beans varieties at different drying temperatures using air-oven has been experimentally studied. The drying processes of three varieties of cocoa beans at 40,50 and 60 ${ }^{\circ} \mathrm{C}$ occur mainly in the range of the falling-rate period. The drying time at $50{ }^{\circ} \mathrm{C}$ is almost doubled that at $60{ }^{\circ} \mathrm{C}$ and more than double at $40^{\circ} \mathrm{C}$. The drying rate of the three varieties at drying temperatures ranged between 0.001 and $0.140 \mathrm{~g}$ water/ $\mathrm{g}$ wet solid $\mathrm{hr}$. The calculated effective diffusivities for three cocoa beans varieties at 40,50 and $60{ }^{\circ} \mathrm{C}$ ranged from $9.9269 \times 10^{-11}$ to $4.4671 \times 10^{-10} \mathrm{~m}^{2} / \mathrm{s}$. The predicted Arrhenius constant $\left(\mathrm{D}_{\mathrm{o}}\right)$ and activation energy $\left(\mathrm{E}_{\mathrm{a}}\right)$ were $2.47 \times 10^{-10} \mathrm{~m}^{2} / \mathrm{s}$ and $23.61 \mathrm{~kJ} / \mathrm{mol}$. These results would be of help in the design of equipment or processes involving drying of different varieties of cocoa beans under forced convection at varying temperature. 


\section{NOMENCLATURE}

$\begin{array}{ll}\mathrm{D} & \text { Arrhenius constant }\left(\mathrm{m}^{2} / \mathrm{s}\right) \\ \mathrm{D}_{\text {eff }} & \text { moisture diffusivity }\left(\mathrm{m}^{2} / \mathrm{s}\right) \\ \mathrm{DR} & \text { drying rate }\left(\mathrm{g} \mathrm{H}_{2} \mathrm{O} / \mathrm{g} \mathrm{wet} \mathrm{solid} \mathrm{h}\right) \\ \mathrm{E} & \text { activation energy }(\mathrm{kJ} / \mathrm{mol}) \\ \mathrm{M} & \text { moisture content }(\%) \\ \text { W } & \text { weight of sample }(\mathrm{g})\end{array}$

\section{Subscripts}

$\begin{array}{ll}\text { bd } & \text { bone dried } \\ d t & \text { change in time (hr) } \\ \mathrm{e} & \text { equilibrium } \\ \mathrm{f} & \text { final } \\ \mathrm{L} & \text { half thickness of slab }(\mathrm{mm}) \\ \mathrm{i} & \text { initial } \\ \mathrm{m} & \text { moisture } \\ \mathrm{MR} & \text { moisture ratio (dimensionless) } \\ \mathrm{R} & \text { Universal gas constant }(8.314 \mathrm{~J} / \mathrm{mol} . \mathrm{K}) \\ \mathrm{t} & \text { time }(\mathrm{s}) \\ \mathrm{T} & \quad \text { temperature }(\mathrm{K})\end{array}$

\section{REFERENCES}

Abdullah, K., 2003, Postharvest technology of cocoa. In Chakraverty A; Mujumdar A.S., Raghavan G.S.V., and Ramaswamy H.S. (Ed.) Handbook of postharvest technology: Cereals, Fruits, Vegetables, Tea and Spices. Marcel Dekker, Inc. New York, 2003.

Adewale, O.O., Afam, I.O.J., and Patrick, F.K., 2015, "Drying kinetics of banana (Musa Spp.)" Interciecia, 40 (6), 374-380.

Akpinar, E.K., Bicer, Y., and Yildiz, C., 2003, "Thin layer drying of red pepper," Journal of Food Engineering 59, 99-104.

https://doi.org/10.1016/S0260-8774(02)00425-9

Alamu, S. A., 2013, "Analysis of Seedling Subsidy Policy and Cocoa Production in South-West Nigeria," Journal of Educational and Social Research, 3(4), 59-62.

https://dx.doi.org/10.5901/jesr.2013.v3n4p59

AOAC, 2000, "Official Methods of Analysis," $17^{\text {th }}$ ed. Association of Official Analytical Chemists, Washington DC, USA.

Bonaparte, A., Alikhani, Z., Madramootoo, C.A., and Raghavan, 1998, "Some quality characteristics of solar dried cocoa beans in St. Lucia," Journal of the Science of Food and Agriculture, 76, 553-558. https://doi.org/10.1002/(SICI)1097-0010(199804)76:4<553::AIDJSFA986 $>3.0 . \mathrm{CO} ; 2-\mathrm{V}$

Chinenye, N.M., Ogunlowo, A.S., and Olukunle, O.J., 2010, "Cocoa Beans (Theobroma Cacao L.) Drying Kinetics," Chilean Journal of Agricultural Research, 70(4): 633-637.

Clement, A.D., Emmanuel, A.N., Patrice, K., Benjamin, Y.K., 2009 "Mathematical Modelling of Sun Drying Kinetics of Thin Layer Cocoa (Theobroma Cacao) Beans" Journal of Applied Sciences Research, 5(9), 1110-1116.

Crank, J., 1975, The Mathematics of diffusion, $2^{\text {nd }}$ Edition, Oxford University press, Oxford, UK.
Darvish, H., Asl, A.R., Asghari, A., Azadbalcht, M., Najafi, G., and Khodaei, J., 2013, "Study of the drying kinetics of pepper," Article in Press.

http://dx.doi.org/10.1016/j.jssas.2013.03.002

Dina, FS., Ambarita, H., Napitupulu, F.H., and Kawai, H., 2015, "Study of continuous solar dryer integrated with desiccant thermal storage for drying cocoa beans," Case Studies in Thermal Engineering, 5, 32 - 40. https://dx.doi.org/10.1016/j.csite.2014.11.003

Dinani, S.T., Hamdami, N., Shahedi, M., and Havet, M., 2014, "Mathematical modeling of hot air/electrohydrodynamic (EHD) drying kinetics of mushroom slices," Energy Conversion and Management, 86, 70-80.

https://dx.doi.org/10.1016/j.enconman.2014.05.010

Doymaz, I., 2005, “Sun drying of figs. An Experimental study," Journal of Food Engineering, 71, 403-407.

https://dx.doi.org/10.1016/j.jfoodeng.2004.11.003

Doymaz, I., 2009, "Experimental study on drying of green apples" Drying technology 27, 478-485.

https://dx.doi.org/10.1080/07373930802686065

Doymaz, I., 2016, "Drying kinetics, rehydration and colour characteristics of convective hot-air drying of carrot slices," Heat mass transfer, http://dx.doi.org/10.1007/s00231-016-1791-8.

Doymaz, I., and Karasu, S., 2018, "Effect of air temperature on drying kinetics, colour changes and total phenolic content of sage leaves (Salvia officinalis)," Quality Assurance and Safety of Crops and Foods, 10(3), 269-276.

http://dx.doi.org/10.3920/QAS2017.1257

El-Sebaii, A.A., and Shalaby, S.M., 2012, "Solar drying of Agricultural products:" A Review. Renewable and Sustainable Energy Reviews, 16, $27-43$.

https://dx.doi.org/10.1016/j.rser.2011.07.134

Fagunwa, A.O., Koya, O.A., and Faborode, M.O., 2009, "Development of an intermittent solar dryer for cocoa beans," Agricultural Engineering International the CIGR Ejournal, Manuscript no. 1292.vol.xi.

Federal Government of Nigeria (FGN) 2006, "National Report" International Conference on Agrarian Reform and Rural Development Porto Alegre, Brazil, pp. 7-10,

Fernando, J.A.K.M., and Amarasinghe, A.D.U.S., 2016, "Drying kinetics and mathematical modeling of hot air drying of coconut coir pith," Research, 5, 807.

https://dx.doi.org/10.1186/s40064-016-2387-y

Hall, C.W., 1980, "Drying and storage of agricultural crops," The AVI publishing coy inc. Westport, Connecticut, USA.

Hamrouni-Sellami, I., Rahali, F.Z., Rebey, I.B., Bourgou, S., Limam, F., and Marzouk, B., 2013, "Total phenolics, flavonoids, and antioxidant activity of sage (Salvia officinalis L.) leaves," Food and Bioprocess Technology, 6, 806-817,

https://dx.doi.org/10.1007/s11947-012-0877-7.

Hii, CL., Tukimon, M.B., 2002, "Evaluation of fermentation techniques practiced by the cocoa smallholders," The Planter, 78(910), 13-22 
Hii, C.L., Law, C.L. and Cloke, M. 2009, "Modelling using a new thin layer model and product quality of cocoa," Journal of Food Engineering, 90, 191-198.

https://dx.doi.org/10.1016/j.jfoodeng.2008.06.022

Hii, C.L., Law, C.L., Cloke, M., and Suzannah, S., 2010. "Improving Malaysian cocoa quality through the use of dehumidified air under mild drying conditions," J. Sci. Food Agric. 91, 239-246.

https://dx.doi.org/10.1002/jsfa.4176

Hii, C.L., Law, C.L., and Suzannah, S., 2012. "Drying kinetics of the individual layer of cocoa beans during heat pump drying," Journal of Food Engineering, 108, 276-282.

https://dx.doi.org/10.1016/j.jfoodeng.2011.08.017

Hii, C.L., Law, C.L., Law, M.C., 2013, "Simulation of heat and mass transfer of cocoa beans under stepwise drying conditions in a heat pump dryer," Applied Thermal Engineering, 54, 264-271.

https://dx.doi.org/10.1016/j.applthermaleng.2013.02.010

Kohli, D., Shahi, N.C., and Kumar, A., 2018, "Drying kinetics and activation energy of Asparagus root for different methods of drying," Current Research in Nutrition and Food Science, 6(1), 191-202. http://dx.doi.org/10.12944/CRNFSJ.6.1.22

Komolafe, C.A., Ogunleye, I.O., and Adejumo, A.O.D., 2011, "The performance evaluation of a convective fish dryer" International Journal of Advances in Science and Technology, 2 (5), 58-64.

Komolafe, C.A., Ogunleye, I.O., Adejumo, A.O.D., and Oladapo, M.O., 2013, "Effects of drying temperatures on the quality of three tilapia fish species," International Journal of Scientific Research and Management, 1 (12), 371-375.

Komolafe, C.A., Adejumo, A.O.D., Awogbemi, O., and Adeyeye, A.D., 2014, "Development of a cocoa beans batch dryer," American Journal of Engineering Research, 3(9), 171-176.
Kuar, K., and Singh, A.K., 2014, "Drying kinetics and quality of characteristics of beetroot slices under hot air followed by microwave finish drying" African Journal of Agricultural Research, 9 (12), 10361044.

http://dx.doi.org/10.5897/AJAR2013.7759

Lin, C.B., and Cze, C.Y., 2018, "Drying kinetics and optimization of pectin extraction from banana peels via response surface methodology," MATEC Web of Conferences 152, 01002.

https://doi.org/10.1051/matecconf/201815201002.

Madamba, P.S., Dricoll, R.H., and Buckle, K.A., 1996, “The thin-layer drying characteristics of garlic slices," Journal of Food Engineering, 26, 113-130.

https://doi.org/10.1016/0260-8774(95)00062-3

McDonald, C.R., Lass, R.A., Lopez, A.S.F., 1981, “Cocoa drying - a review. Cocoa Growers" Bull, 31, 5-41

Memmert Expert in Thermostatics 2013, "Manufacturer operating instructions" p.10.

Mujumdar, AS., 2006, "Principles, classification, and selection of dryers," In handbook of industrial drying, Ed; Mujumdar, A.S. Taylor and Francis Group LLC part I, 18-47.

Sadaka, S., and Atungulu, G., 2018, "Grain sorghum drying kinetics," BioResources, 13(1), 1534 - 1547

Sampaio, R.M., Neto, J.P.M.., Perez, V.H., Marcos, S.K., Boizan, M.A., and Dasilva, L.R., 2016, Journal of Food Processing and Preservation, ISSN 1745-4549.

http://dx.doi.org/10.1111/jfpp.12789

Schwan, R. F., Rose, A.H., and Board R.G., 1995, "Microbia fermentation of cocoa beans with emphasis on enzymatic degradation of the pulp," Journal of Applied Bacteriology Simposium Supplement, 79, 965- 1075. 